\title{
Exploration of Learning Obstacle Based on Mathematical Understanding of Algebra in Junior High School
}

\author{
Muchamad Subali Noto ${ }^{1 *}$, Surya Amami Pramuditya ${ }^{2}$, Via Dwi Handayani ${ }^{3}$ \\ 1,2,3 Universitas Swadaya Gunung Jati, Cirebon, Indonesia \\ *Corresponding author: msnoto.ugj@gmail.com
}

\begin{tabular}{|c|c|}
\hline a rticl ein fo & abstract \\
\hline How to cite this article: & EXPLORATION OF LEARNING OBSTACLE BASED ON \\
\hline Noto, M.S., $\operatorname{Pr}$ & MATHEMATICAL UNDERSTANDING OF ALGEBRA IN \\
\hline (2020). Exploration of Learning Obstacle Based on & JUNIOR HIGH SCHOOL. The difficulty of students related to \\
\hline Mathematical Understanding of Algebra in Junior & algebra arises from the lack of students' mathematical \\
\hline High School. Eduma : Mathematics Education & understanding and Learning Obstacle (LO). One of the LO's \\
\hline $\begin{array}{l}\text { Learning And Teaching, 9(1), } 14 \text { - } 20 . \\
\text { doi:http://dx.doi.org/10.24235/eduma.v9i1.5946 }\end{array}$ & experienced by students is the epistemological obstacle in the form \\
\hline & $\begin{array}{l}\text { of the limited knowledge possessed by students in mathematical } \\
\text { concepts related to algebraic form. The purpose of this study is to } \\
\text { explore LO related to algebra material. This research method is }\end{array}$ \\
\hline Article history: & qualitative with the consisted of 15 students of 7 th grade. The \\
\hline Received: 01 17, 2020 & $\begin{array}{l}\text { results showed that the common students could not interpret } \\
\text { concepts and clarify the elements of algebraic forms related to }\end{array}$ \\
\hline Accepted: 02 18, 2020 & variables, coefficients and constants and students could not operate \\
\hline Published: 07, 2020 & $\begin{array}{l}\text { and simply algebraic forms. The teacher can make pedagogical and } \\
\text { didactic anticipations to overcome the LO. }\end{array}$ \\
\hline
\end{tabular}




\section{INTRODUCTION}

Mathematics is a subject that has become an important element in the development of science and technology (Wulandari, Mujib, \& Putra, 2016). According to Uno (2007) that mathematics is a tool, communication, a tool to solve as a practical problem, the elements of which are logic and intuition of analysis and construction, generality and individuality, and have branches including arithmetic, algebra, geometry, and analysis. Therefore, mathematics is very important to learn because it is an exact science that is the basis of all fields of science and needs to be given early on to students to have a logical, critical and systematic mindset especially in mathematical abilities (Firdaus etc all, 2015).

Students must master several mathematical abilities. Hendriana and Soemarmo (2014) explain that one of these mathematical abilities is understanding. Understanding is a very important aspect for students in the principles of mathematics learning (Mulyani, Indah, \& Satria, 2018). The importance of mathematical understanding is to achieve meaningful learning. Mathematical learning must be directed at developing mathematical connection abilities between ideas, understanding mathematical ideas interrelated with each other so that a comprehensive understanding is built up, and using mathematics in contexts outside mathematics (NCTM, 2000; Hendriana, Rohaeti, \& Sumarmo, 2017). Therefore mathematical understanding is very important for students and will be more meaningful if it built by the students themselves. This means that mathematical concepts are easier to understand and not easily forgotten.
Based on reality, students' mathematical understanding is still low and needs to be improved (Chotimah, 2014; Mulyani, Indah, \& Satria, 2018). According to Purwasih (2015), several factors cause the low mathematical understanding of Indonesian students, including students accustomed to learning mathematical concepts and formulas by memorizing without understanding their purpose, content, and usefulness. One of the concepts that has a low mathematical understanding is algebra at the junior high school. In the learning process, students have difficulties in operatibg algebraic form (Booth \& Koedinger, 2008; Saputro, Suryadi, Rosjanuardi, \& Kartasasmita, 2018; Astuti \& Sari, 2018). Some of these difficulties can hinder students' understanding of learning algebraic forms more deeply (Lange, Both, \& Newton, 2014). The difficulty of students in learning algebra lies in the basic concepts related to the elements of algebraic forms and the operation of algorithmic forms of algebra (Malihatuddarojah \& Prahmana, 2019). Learning difficulties is the expression of learning obstacles.

Brousseau (2002) argues that learning obstacles experienced by students come from various sources including ontogeny obstacle, didactical obstacle and epistemology obstacle. Ontogenic obstacle related to the mismatch between the learning provided with the level of thinking of students, thus raising difficulties in the process of understanding the material. Didactical obstacle related to difficulties that occur due to learning by the teacher. Epistemological obstacles related to difficulties in the learning process that occur as a result of the limited context that students know. This research is more focused on epistemological obstacle 
because of the limited context of students' knowledge in learning algebraic form. The purpose of this study is to explore student obstacle learning related to algebraic form.

\section{METHODS}

The research method used was qualitative. The research subjects consisted of 15 students of 7 th grade. The procedure in this study consisted of three stages namely preparation, implementation and analysis of data. In the preparation stage, researchers arrange questions about the ability to understand mathematical forms of algebra. Table 1 presents the test questions used along with indicators of their mathematical understanding.

Table 1

Instrument and Mathematical Understanding Indicators

\section{Mathematical}

No Understanding

Skill

Indicators

1. Restate the Problem 1 concepts that By using your own have been word, please learned. define the meaning of variables, coefficients and constants?

2. Clarify objects Problem 2 based on Name each whether or not element of this the algebraic form of requirements $2 x+9$ ? that form the concept are met.

3. Apply concepts Problem 3 algorithmically. Find the sum of $16 a-12 b+4$ and $5 a-9 b+2 c$

4. Apply concepts Problem4 algorithmically. Subtract $3 x+4 y$ by $5 x-6 y$

$\begin{array}{lll}\text { 5. } & \text { Apply concepts } & \text { Problem5 } \\ \text { algorithmically. } & \text { Simplify the } \\ & \text { algebraic form } \\ & 9 a^{2}+3 a b-7 b^{2}- \\ & 12 a^{2}+6 a b+2 b^{2}\end{array}$

At the implementation stage, the researcher gave an instrument of understanding and conducted interviews to several students. Next, the researcher analyzed the students' answers to explore the learning obstacles experienced by students. Data were analyzed qualitatively by triangulation technique.

\section{RESULT AND DISCUSSION}

The results show that students' LO related to students' understanding, including: LO related to the elements of algebraic forms, the addition and subtraction operations of algebraic forms. LO related to the elements of algebraic form is obtained based on students' answers to Problem 1.

Problem 1 was included in order to measure students' ability to restate the concepts that have been learned. Students were asked to express what they mean by variables, coefficients and constants according to their individual understanding.

Based on the answer, students described the elements of algebraic form according to their own understanding. They were right in defining coefficients and constants when using their own word, while in defining variables, students defined them incorrectly. The inaccuracy of students showed that students did not understand the meaning of the elements of algebraic forms themselves, especially variables. Students tended to mention that a variable was a letter. In their minds the variables are the letters $\mathrm{x}$ and $\mathrm{y}$. This was reinforced by the results of researchers' interviews with one of the students who showed that the variables were letters in algebra such as $\mathrm{x}, \mathrm{y}$ and $\mathrm{z}$. Of the 15 students in answering question 1 , a total of 4 students were incorret in defining variables, coefficients and 
constants, 7 students who defined using their own language but were not yet precise and 4 students who could not at all in defining variables, coefficients and constants. Student errors on variables could occur due to the use of teaching materials and methods that were not appropriate during the learning process (Badaruddin, Tengah, \& Prahmana, 2018).

Problem 2 included indicators about the ability to clarify objects based on whether or not the requirements that form the concept are met. Students were asked to clarify objects in the form of algebra which shows variables, coefficients and constants. Students answer can be seen as follows.

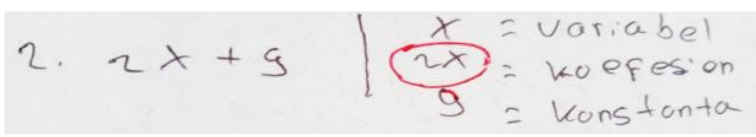

Figure 1 Students' answers to problem number 2

Figure 1 shows that students could not clarify the elements of algebraic form. Student did the misconceptions in showing incorrect coefficients. Students tended to show coefficients and variables simultaneously which result in misconceptions in learning algebraic forms. Students could not determine which was a variable, coefficient or constant. Of the 15 students who answered question 2 there were 5 students' answers that were correct, 5 students who made mistakes in these and 5 students who did not understand the elements of the algebraic form. This was similar to Utami's study (2019) that of 31 students other Junior High School in Indonesia, 18 students (58\%) experienced misconceptions, while students who did not experience misconceptions were 13 (42\%). Factors that cause misconceptions were students 'low memory capacity, students' cognitive development that was not in accordance with the instructional materials they are interested in, and their low learning interest in algebraic material.
Problem 3 included indicators about the ability to apply algebraic concepts algorithmically. Students were asked to determine the sum of the given problem. Students answer the questions as follows.

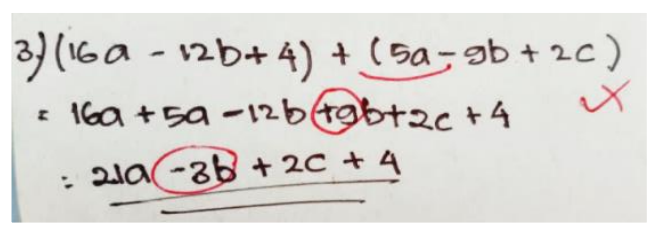

Figure 2 Students' answers to problem number 3

Figure 2 shows that students did not follow on the algorithm, they should open the parentheses that have been operated first, then classified similar terms and operated them to the simplest form. In addition, students were said to be less able to operated integers so that students were most likely incorrect in determining the results of their operations and did not answer them correctly. Lack of students' understanding in the concept of integer operations, especially working on addition or subtraction operations with negative terms results in incorrect results (Malihatuddarojah \& Prahmana, 2019). This shows that the understanding of intervention he obtained is when they were studying negative numbers (Booth, Barbieri, Eyer, \& Paré-Blagoev, 2014). Of the 15 students who answered problem 3 , as many as 11 students in the process of answering questions were not systematic resulting in inaccuracies in integer calculations, as many as 2 students who could not answer questions because students' knowledge in understanding the concept of total algebra was very limited and as many as 2 students were said to be able to the process of solving algebraic forms correctly.

Problem 4 included indicators about the ability to apply concepts algorithmically. 
Students were asked to determine the algebraic reduction in algorithmic operations. They answered the problem as follows.

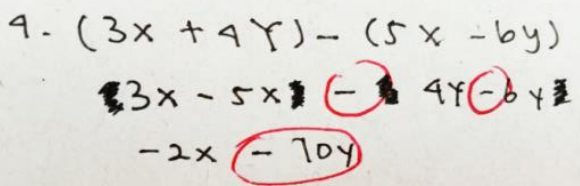

Figure 3 Students' answers to problem number 4

Figure 3 shows the student not following on the algorithm, he should open the parentheses that have been operated, then classify similar terms and operate to the simplest form. They misconstrued in solving the problem because they immediately grouped similar terms and ignored the subtraction operations so that they did not operate algorithmically and affected the final value that was not right. The other students' answers in Figure 4 are as follows.

$$
\text { 4. } \begin{aligned}
& (3 x+4 y)-(5 x-6 y) \\
(3 x-5 x) & (4 y-6 y) \\
= & -2 x-2 y
\end{aligned}
$$

Figure 4 Students' answers to problem number 4

Figure 4 shows students incorret in understanding the problem. They solve the problem without giving parentheses first, but in the second line they give parentheses to group similar term and ignore the deduction operation signs. They misconstrued the problem in solving the problem causing misconceptions on algebraic operations.

Based on Figure 4 and Figure 5, it can be concluded that students have the incorrect concept in solving problems. They immediately classified the same term and ignore the subtraction operation so students operate it not algorithmically and affect the final grade that is not right. This is similar to research conducted by Nugraha, Kadarisma, \& Setiawan (2019) in one of other Indonesia junior high schools, students have a lack of understanding of positive and negative operations, lack of understanding of reading problems, errors in calculations and use of the incorrect process. However, in this study students were correct in calculations, only the use of the incorrect process. Of the 15 students who answered problem 4, 9 students answered questions with incorrect concepts and the use of the incorret process in operating the reduction of algebraic forms and as many as 6 students were able to answer correctly but still not algorithmically.

Problem 5 included indicators about the ability to apply concepts in an algorithmic way. Students were asked to simplify the operations of addition and subtraction of algebraic forms. They answered the problem as follows.

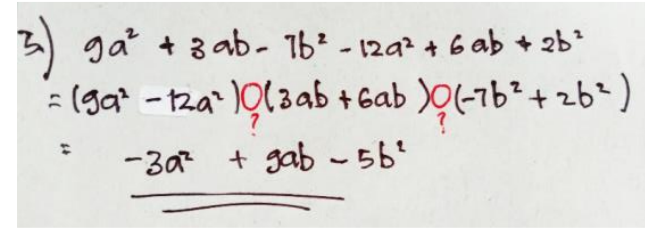

Figure 5 Students' answers to problem number 5

Figure 5 shows students solving these problems by grouping similar terms but not using the sign of the operation causing misunderstanding in the operation of reducing and adding algebraic forms. Even though the final answer is said to be correct, but in the use of the incorrect process and simplifying it is not algorithmically. Based on the results of researchers' interviews with one of the students, it was found that they did not use operation marks because they forgot and were not thorough in solving the problem. This problem is not due to the weaknesses of student learning, but is a mistake that requires cognitive tasks so that they are aware of the mistakes they have made (Zubainur \& Ali, 2018). Of the 15 students who answered question number 5 , a total of 4 students whose final answers were said to be correct but in the process were not algorithmically employed, as many as 8 students 
answered questions by grouping similar term but did not use operating marks, and as many as 3 students who answered questions incorrectly in operating it.

Based on LO analysis, it can be concluded that students in Indonesian high school had epistemological obstacles, namely student learning difficulties caused by the limited knowledge that students had in mathematical concepts related to algebraic form material. This is similar to research (Mulyani, Indah \& Satria, 2018), students do not apply formulas in simple calculations but students have done calculations algorithmically and associate one concept with another concept.

But there are differences in this research that students solve algebraic form problems not algorithmically and they cannot simplify the algebraic form in the simplest form. Likewise with research conducted by (Malihatuddarojah \& Prahmana, 2019), students have a lack of understanding of the rules of combining variables in algebra, lack of students' understanding of integer operations concepts, lack of students' understanding of concepts simplifying the form of algebraic equations and lack of students' understanding of concepts addition, subtraction, multiplication, and division of algebraic forms. So it can be said that junior high school students in several Indonesian schools have the same learning obstacles related to the form of algebra.

\section{CONCLUSION AND IMPLICATION}

The conclusions of this study are (1) Learning obstacle students in one of the junior high schools in Indonesia is epistemology obstacle and

Epistemology obstacle obtained is that students do not interpret the elements of algebraic forms related to variables, coefficients and constants and they cannot operate forms algorithmic algebraic form.

This research can be the basis for designing a didactic situation in Didactical Design Research (DDR) for algebra material in junior high school.

\section{REFERENCES}

Astuti \& Sari, N. (2018). Analisis kesulitan belajar struktur aljabar di STKIP Pahlawan Tuanku Tambusai. Jurnal Pendidikan Matematika, 12 (2), 73 - 80. https://doi.org/10.22342/jpm.12.2.4142.7 $3-80$

Badaruddin, D. P., Tengah, K. A., \& Prahmana, R. C. I. (2018). Enhancing manipulation of algebraic equation through Balance Method. Journal of Physics: Conference Series, 1088(1), 012007. https://doi.org/10.1088/17426596/1088/1/012007

Booth, J. L., \& Koedinger, K. R. (2008). Key misconceptions in algebraic problem solving. Proceedings of the Annual Meeting of the Cognitive Science Society, 30(30), 571-576. https://escholarship.org/uc/item/5n28t12 $\mathrm{n}$

Booth, J. L., Barbieri, C., Eyer, F., \& ParéBlagoev, E. J. (2014). Persistent and pernicious errors in algebraic problem solving. The Journal of Problem Solving, 7(1), 10-23. https://doi.org/10.7771/19326246.1161

Brousseau, G. (2002). Theory of didactical situations in mathematics: Didactique des mathématiques, 1970-1990 (Vol. 19). Springer Science \& Business Media.

Chotimah, S. (2014). Upaya Meningkatkan Kemampuan Pemahaman Matematik Siswa dengan Pendekatan Realistic Mathematics Educations pada Siswa SMP di Kota Bandung. Prosiding Seminar Nasional Pendidikan Matematika. 2, (pp.133-139). Cimahi: STKIP Siliwangi. 
Firdaus, F., Kailani, I., Bakar, M. N. B., \& Bakry, B. (2015). Developing critical thinking skills of students in mathematics learning. Journal of Education and Learning, 9(3), 226-23 https://doi.org/10.11591/edulearn.v9i3.1 830

Hendriana, H., Rohaeti, E. E., \& Sumarmo, U. (2017). Hard skills dan soft skills matematik siswa. Bandung: Refika Aditama.

Hendriana, H., \& Soemarmo, U. (2014). Penilaian pembelajaran matematika. Bandung: Refika Aditama.

Lange, K. E., Booth, J. L., \& Newton, K. J. (2014). Learning algebra from worked examples. MatheMatics teacher, 107(7), 534-540.

https://doi.org/10.5951/mathteacher.107. 7.0534

Malihatuddarojah, D., \& Prahmana, R. C. I. (2019). Analisis Kesalahan Siswa dalam Menyelesaikan Permasalahan Operasi Bentuk Aljabar. Jurnal Pendidikan Matematika, 13(1), 1-8. https://doi.org/10.22342/jpm.13.1.6668.18

Mulyani, A., Indah, E. K. N., \& Satria, A. P. (2018). Analisis Kemampuan Pemahaman Matematis Siswa SMP pada Materi Bentuk Aljabar. Mosharafa: Jurnal Pendidikan Matematika, 7(2), 251-262.

https://doi.org/10.31980/mosharafa.v7i2. 24

NCTM (2000). Principles and Standards for School Mathematics. Reston, VA: The National Council of Teachers of Mathematics, Inc.

Nugraha, N., Kadarisma, G., \& Setiawan, W. (2019). Analisis Kesulitan Belajar Matematika Materi Bentuk Aljabar Pada Siswa SMP Kelas VII. Journal on Education, 1(2), 323-334. Retrieved from http://jonedu.org/index.php/joe/article/vi ew/72
Purwasih, R. (2015). Peningkatan Kemampuan Pemahaman Matematis dan Self Confidence Siswa MTS di Kota Cimahi Melalui Model Pembelajaran Inkuiri Terbimbing. Didaktik, 9(1), 16-25. Retrieved from http://ejournal.stkipsiliwangi.ac.id/index.php/di daktik/article/view/113

Saputro, B. A., Suryadi, D., Rosjanuardi, R., \& Karta sasmita, B. G. (2018). Analysis of students' errors in responding to TIMSS domain algebra problem. Journal of Physics: Conference Series , 1088 (1), 012031. https://doi.org/10.1088/17426596/1088/1/012031

Suryadi, D. (2013). Didactical design research (DDR) to improve the teaching of mathematics. Far East Journal of Mathematical Education, 10(1), 91-107.

Uno, H. B. (2007). Model pembelajaran menciptakan proses belajar mengajar yang kreatif dan efektif. Jakarta: Bumi Aksara.

Utami, R. (2019). Analisis Miskonsepsi Siswa Dan Cara Mengatasinya Pada Materi Bentuk Aljabar Kelas VII-C SMP Negeri 13 Malang. JPM: Jurnal Pendidikan Matematika, 3(1), 37-44. https://doi.org/10.33474/jpm.v3i1.2606

Wulandari, P., Mujib, M., \& Putra, F. G. (2016). Pengaruh model pembelajaran investigasi kelompok berbantuan perangkat lunak MAPLE terhadap kemampuan pemecahan masalah matematis. Al-Jabar: Jurnal Pendidikan Matematika, 7(1), 101-106. https://doi.org/10.23887/jppm.v8i2.2853

Zubainur, C. M., \& Ali, R. M. (2018, September). Cognitive conflict strategy to minimize students' misconception on the topic of addition of algebraic expression. In Journal of Physics: Conference Series (Vol. 1088, No. 1, p. 012084). IOP Publishing. https://doi.org/10.1088/17426596/1088/1/012084 